\title{
Alcohol Dehydrogenase of a Novel Algae Fermentation Strain Meyerozyma guilliermondii
}

\author{
W. Zhang,,${ }^{\text {a, }}$ Z. Zhang, ${ }^{\text {a }}$ L. Bao, ${ }^{\mathrm{b}}$ X. Zhang, ${ }^{\text {a }}$ and H. Cui ${ }^{\mathrm{a}}$ \\ ${ }^{a}$ College of Environment and Chemistry Engineering, \\ Yanshan University, Qinhuangdao 066004, China \\ 'Institute of Forensic Science of Ministry \\ of Public Security P.R.C., Beijing 100038, China
}

doi: 10.15255/CABEQ.2016.836

Original scientific paper

Received: February 11, 2016

Accepted: January 30, 2018

The production of bioethanol from algae has attracted wide attention in the field of energy. A novel algae fermentation strain, Meyerozyma guilliermondii, can produce alginate lyase and alcohol dehydrogenase (ADH) at the same time. At present, there is no research on the fermentation conditions, separation, and purification of the alcohol dehydrogenase of Meyerozyma guilliermondii. In this research, the fermentation conditions of Meyerozyma guilliermondii, the separation, and purification processes of alcohol dehydrogenase, and the performance study of alcohol dehydrogenase were studied. According to the experimental results, the optimum fermentation conditions for enzyme production

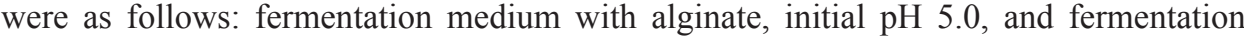
temperature of $30{ }^{\circ} \mathrm{C}$. The highest enzyme activity reached $69.9 \mathrm{U} \mathrm{mL}^{-1}$ crude enzyme. The optimal treating time of the ultrasonic separation procedure was $12 \mathrm{~min}$ at power of $320 \mathrm{~W}$. The suitable purification method of the enzyme was salting out and dialysis method. When saturation reached $50 \%$, the total enzyme activity was the highest. Finally, the properties of enzyme were studied in this research. The maximum activity was reached at $\mathrm{pH}$ 7. The optimum temperature of $\mathrm{ADH}$ activity was $35^{\circ} \mathrm{C}$.

Keywords:

algae fermentation strains, ethanol production, alcohol dehydrogenase

\section{Introduction}

The aggravating energy crisis, the concern about the climate change caused by greenhouse gas emissions, and the limited fossil fuel resources have led to the development of renewable energy technologies, therefore, most of the research is focused on the utilization of biomass to produce ethanol ${ }^{1-3}$. Bioethanol is a typical clean and renewable liquid fuel4. Bioethanol is made by microbial fermentation, mostly from carbohydrates produced in sugar or starch plants, such as corn ${ }^{5}$, sugar cane ${ }^{6}$, sweets sorghum $^{7}$ or lignocellulosic biomass ${ }^{8}$. The higher amounts of corn turned over for biofuel production could have devastating effects on the food supply around the world. A promising solution to this problem is bioethanol production from lignocellulose materials. However, some difficulties are still present in the production of cellulosic ethanol on a commercial scale, such as the complex processes required to release simple sugars from recalcitrant polysaccharides $^{9,10}$.

In order to meet the expected increasing demand for bioethanol, there is a need to find alterna-

${ }^{*}$ Corresponding author. Tel./fax: +86 03358387746

E-mail address: gillianjay@126.com (Wen Zhang) tive biomass sources, particularly those that do not rely on large amounts of agricultural land ${ }^{11,12}$. Marine seaweed is a potential biomass resource for the full or partial substitution and displacement of terrestrial biomass to produce sustainable biofuels and biochemical products ${ }^{13,14}$. The utilization of algae for bioethanol production has many advantages due to their abundance, high photosynthetic efficiency, and production rate. Another advantage is that the lignin content of algae is very low, so the sugar can be released through a simple process. However, the sugar composition of algae is very complex especially alginate composition, which is hardly used by microorganisms. In order to solve this problem, genetic engineering microorganism was used in the fermentation of algae. Nevertheless, there were still drawbacks in the genetically modified strain, because ethanol production of this strain was under aerobic conditions, and oxygen supply required strict control in order to maintain a balance between energy and ethanol production, since oversupply of oxygen would lead to low ethanol production.

Research on the native fermentation strain and the ethanol fermentation metabolism of the native algae fermentation strain is lacking. In our previous research, a novel algae fermentation strain was ob- 
tained, which was $99 \%$ identical to Meyerozyma guilliermondii $^{15}$. At the same time, ethanol fermentation experiments of this strain were performed. This strain is able to produce alginate lyase and ethanol dehydrogenase during the fermentation process. The ethanol yield rate of $L$. japonica reached $0.237 \mathrm{~g} \mathrm{~g}^{-1}$ ethanol to L. japonica. This suggested that the strain might be promising for ethanol production from algae. Ethanol production is related to ethanol dehydrogenase ${ }^{16}$. Alcohol dehydrogenase $(\mathrm{ADH})$ is responsible for the production of ethanol by yeast ${ }^{17}$. This enzyme is the most important enzyme in ethanol fermentation.

At present, there is no research on the fermentation conditions, separation, and purification of ethanol dehydrogenase of Meyerozyma guilliermondii, especially when the carbon source is alginate. Further studies on ethanol dehydrogenase would be beneficial to the study of the ethanol metabolic mechanism and optimization of the enzyme fermentation process by Meyerozyma guilliermondii. Therefore, in this research, the fermentation conditions of Meyerozyma guilliermondii, the separation and purification processes of alcohol dehydrogenase, and the performance study of alcohol dehydrogenase was studied.

\section{Materials and methods}

\section{Materials}

All chemicals of analytical reagent grade were purchased from Beijing Chemical Factory (Beijing, China). All the biochemical reagents were bought from Beijing Biological Technology Factory (Beijing, China). The strains were stored in the tube culture at $4{ }^{\circ} \mathrm{C}$, and stored in glycerol solution ${ }^{18}$. General biological equipment was purchased from Shanghai Precision Instrument Co., LTD (Shanghai, China).

\section{Culture media and microorganism culture}

Yeast Extract Peptone Dextrose Medium (YPD medium) was used as the enrichment medium containing $10 \mathrm{~g} \mathrm{~L}^{-1}$ yeast extract, $20 \mathrm{~g} \mathrm{~L}^{-1}$ peptone, and $20 \mathrm{~g} \mathrm{~L}^{-1}$ glucose. In addition, the $\mathrm{pH}$ of YPD medium was adjusted to $4-5$. The agar (2\%) was added to the YPD medium to make YPD solid culture medium. The enzyme fermentation culture medium contained different carbon source, yeast extract, and peptone.

\section{Fermentation experiments of ADH}

The enzyme fermentation experiments were carried out in flasks with $30 \mathrm{~mL}$ working medium. The glycerol frozen stored strain was firstly put in
$37{ }^{\circ} \mathrm{C}$ water bath for rapid thawing, and then plate-streaking recovery was performed. The survival conditions and relevant biochemical parameter of the strain were detected and the colony morphology was observed. If the cells and colony morphology observed by microscope did not change compared with the original species, and the growth state was good, the strain was used for further experiments. Strains with high dehydrogenase activity were first activated in YPD broth for $24 \mathrm{~h}$ in a shaking incubator at $150 \mathrm{rpm}, 30{ }^{\circ} \mathrm{C}$, and then inoculated to the enzyme fermentation medium with inoculum amount of $5 \%$. The flasks were autoclaved at $121{ }^{\circ} \mathrm{C}$ for $15 \mathrm{~min}$, inoculated with various strains after cooling to room temperature. All the flasks were cultured in a shaking incubator, with culture conditions as follows: $200 \mathrm{rpm}$ for $24 \mathrm{~h}$. The effect of temperature, initial $\mathrm{pH}$, and flask volume on enzyme activity were studied. Experiments were performed in the fermentation medium at temperatures varying from $20{ }^{\circ} \mathrm{C}$ to $40{ }^{\circ} \mathrm{C}$, initial $\mathrm{pH}$ varying from 3 to 8 , and flask volumes from 100 to $300 \mathrm{~mL}$. At the same time, fermentation was carried out with different substrates, such as laminaran, mannitol, alginate and glucose (all $20 \mathrm{~g} \mathrm{~L}^{-1}$ ), while the other components $\left(20 \mathrm{~g} \mathrm{~L}^{-1}\right.$ peptone and $10 \mathrm{~g} \mathrm{~L}^{-1}$ yeast extract) remained the same.

\section{Separation of alcohol dehydrogenase}

The enzyme was to be separated from the fermentation broth. After cultured in the shaking incubator, $30 \mathrm{~mL}$ fermentation liquor was centrifuged at $5000 \mathrm{rpm}$ for $5 \mathrm{~min}$, and the cells were washed and suspended in $20 \mathrm{~mL} \mathrm{K-phosphate} \mathrm{buffer}\left(0.05 \mathrm{~mol} \mathrm{~L}^{-1}\right.$, $\mathrm{pH}$ 8.0). An amount of $200 \mu \mathrm{L} 32 \mathrm{mg} \mathrm{mL}^{-1}$ lysozyme was added and the mixture was kept at $37^{\circ} \mathrm{C}$ for $30 \mathrm{~min}$. The beaker containing the solution was then put in iced water and the cells were disrupted by ultrasonic cell disintegrator, which proceeded as follows: ultrasonic disruption for $1 \mathrm{~s}$, pause $3 \mathrm{~s}$, and the whole time of the procedure was changed from 5 to $20 \mathrm{~min}$ under power of $320 \mathrm{~W}$. The solution was then centrifuged at $10000 \mathrm{rpm}$ for $15 \mathrm{~min}$. The supernatant was kept and stored at $4{ }^{\circ} \mathrm{C}$. This supernatant was the crude enzyme.

\section{Purification of alcohol dehydrogenase}

The crude enzyme mixture was put in an ice bath, and ammonium sulfate was added into the solution to reach certain saturation of $50 \%$ under the action of a magnetic stirrer. After standing for $10 \mathrm{~min}$, the solution was centrifuged at $12000 \mathrm{rpm}$ for $20 \mathrm{~min}$. The precipitation was collected and then dissolved in $1 \mathrm{~mL}$ PBS, and transferred to $1.5 \mathrm{~mL}$ centrifuge tube. The enzyme mixture was then treated by dialysis method. The dialysis bags were cut to 
the appropriate length $(10-20 \mathrm{~cm})$, and then put in $1 \mathrm{mmol} \mathrm{L}{ }^{-1}$ EDTA ( $\mathrm{pH}$ 8.0) solution and boiled for 10 min. The dialysate was PBS solution $(\mathrm{pH} 6.0,40$ mmol $\left.\mathrm{L}^{-1}\right)$. In addition, the dialysate solution was regularly replaced with a new solution after $4 \mathrm{~h}, 8$ $\mathrm{h}$, and $14 \mathrm{~h}$. After the last replacement of dialysate, the dialysis continued for $2 \mathrm{~h}$. After dialysis treatment, the sample was dried. The reason for drying is that the enzyme in solution is generally less stable than solid, and may easily be contaminated by microorganisms, which is often difficult to preserve without losing its activity. Dehydration method was freeze-drying at temperature of $-50{ }^{\circ} \mathrm{C}$, vacuum degree of $10 \mathrm{~Pa}$, and drying time of $24 \mathrm{~h}$.

\section{Research of enzyme ADH properties}

In order to confirm the enzyme's scope of application, the enzyme activity was measured under different $\mathrm{pH}$ conditions (3-11), and the optimum $\mathrm{pH}$ of the enzyme was obtained. At the same time, the enzyme was mixed with the buffer solution under different $\mathrm{pH}$ for different times ( $1 \mathrm{~h}$ and $2 \mathrm{~h}$ ), then the enzyme activity was measured. The temperature also affected the activity of the enzyme, so in this research, under different temperatures (20$60{ }^{\circ} \mathrm{C}$ ), the enzyme activity was measured, and the optimum temperature obtained.

\section{Analytical methods}

The enzyme activity was measured according to a refined method based on reference ${ }^{19}$. Tris- $\mathrm{HCl}$ buffer $(\mathrm{pH}=8.5)$ was mixed with enzyme solution at $37{ }^{\circ} \mathrm{C}$ for preheating of $5 \mathrm{~min}$, and then $2 \mathrm{M}$ ethanol was added. Later, $4.5 \mathrm{mM} \mathrm{NAD}^{+}$solution was added and mixed to test the absorbance value at the wavelength of $340 \mathrm{~nm}$. In addition, the absorbance change of 0.001 in one minute at $340 \mathrm{~nm}$ was used as an active unit. The $\mathrm{pH}$ was measured in a $\mathrm{pH}$ meter (PHS-3B, Shanghai Precision \& Scientific Instrument Co. Ltd, Shanghai, China). Cell growth in the YPD culture medium was measured with a spectrophotometer (Shanghai precision instrument co., LTD (Shanghai, China)) at $600 \mathrm{~nm}$. The determination of the biomass was through the collection of wet cells after centrifugation and the determination of quality according to reference ${ }^{20}$. All experiments were carried out four times.

\section{Results and discussion}

\section{Fermentation conditions of alcohol dehydrogenase}

There are many factors that influence the activity of alcohol dehydrogenase in the fermentation process by Meyerozyma guilliermondii, such as car-

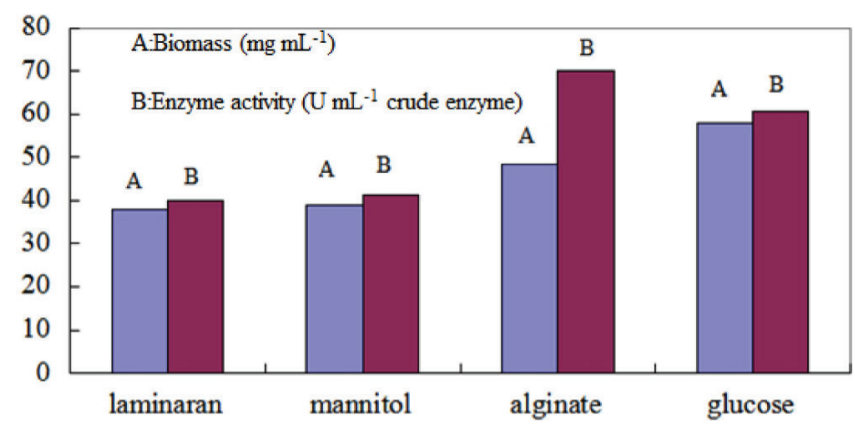

Fig. 1 - Enzyme fermentation with different carbon sources

bon source, $\mathrm{pH}$, and so on. In this research, different fermentation conditions, such as carbon source, initial $\mathrm{pH}$ of the fermentation solution, fermentation temperature, and ventilation quantity were chosen for the production of alcohol dehydrogenase.

Nutrient conditions play an important role in the production of enzyme. Carbon source is very important in the production of ADH and is the provider of cell carbon and metabolism energy ${ }^{21}$. In the fermentation process, the carbon source helps build the microbial cell, provide energy for microbial life activities, and produce enzyme components. The carbon source can also act as enzyme inducer. In this experiment, four different carbon sources were chosen in the same concentration of enzyme fermentation, and the initial $\mathrm{pH}$ of fermentation medium was 5. The results are shown in Fig. 1. In this paper, the strain Meyerozyma guilliermondii was chosen for enzyme production. This strain was isolated from wine lees with alginate as the only carbon source, and showed high ethanol fermentation ability. This fermentation strain was able to utilize many components of algae to produce ethanol. So laminaran, mannitol, alginate and glucose were selected as carbon source composition of the fermentation carbon source. After the fermentation of different carbon sources, the crude enzyme was prepared according to the process introduced in Section "Separation of alcohol dehydrogenase", and the time of the ultrasonic procedure was $15 \mathrm{~min}$. The result showed that alginate produced the highest enzyme activity. This conclusion was different from other literature ${ }^{22}$, which commonly used glucose as the carbon source of alcohol dehydrogenase fermentation. In the subsequent experiments, alginate was also used as fermentation medium carbon source.

In the process of enzyme fermentation, temperature control is very important, because the microbial growth and enzyme fermentation production need certain temperature conditions ${ }^{23}$. Different cells have their optimum growth temperature. The optimum growth temperature and enzyme production by fermentation are always different. Therefore, in this fermentation experiment, different tem- 
perature conditions were set from $20^{\circ} \mathrm{C}$ to $40{ }^{\circ} \mathrm{C}$. The results are shown in Fig. 2. From the experimental results, the temperature had certain influence on microbial growth reproduction. Under the condition of $35^{\circ} \mathrm{C}$, the maximum biomass was obtained, and at $30{ }^{\circ} \mathrm{C}$ the total enzyme activity was the highest. The optimum enzyme fermentation temperature was lower than the optimum temperature of microorganism growth. In our previous research, when the fermentation temperature was $30{ }^{\circ} \mathrm{C}$, the ethanol yield rate also reached the highest ${ }^{15}$.

During the fermentation process, the cell was very sensitive to the $\mathrm{pH}$ of the medium ${ }^{24}$. Bacteria and actinomycete like neutral and alkaline environments, whereas yeasts and molds like partially acidic environments. The optimum $\mathrm{pH}$ of enzyme fermentation and the cell growth is often different. Therefore, in this fermentation experiment, different initial $\mathrm{pH}$ conditions were set from 3 to 8 . The results are presented in Fig. 3. As shown in Fig. 3, the enzyme activity was higher when the $\mathrm{pH}$ ranged from 4 to 6 . The initial $\mathrm{pH}$ value of fermentation solution had significant influence on the total amount of enzyme, and the enzyme activity of crude enzyme was quite different. The enzyme activity of the crude enzyme was highest at $\mathrm{pH}$ 5. In addition, the biomass reached maximum at $\mathrm{pH} 6$.

In this experiment, different volumes of conical flasks were selected to judge the ventilation effect on enzyme fermentation. Oxygen is very important for cell growth and reproduction ${ }^{25}$. The preliminary experiments also proved that the appropriate ventilation in the prefermentation period was conducive to improve ethanol production rate. The results are presented in Fig. 4. The experimental results showed that cell biomass increased with larger volume of the conical flask, but the total amount of enzyme production had not significantly increase. When the conical flask was larger in volume, enzyme activity of per unit biomass was reduced.

According to the experiments, the optimum fermentation conditions of enzyme production were as follows: fermentation medium with alginate, initial $\mathrm{pH} 5.0$, and $30{ }^{\circ} \mathrm{C}$. The total capacity of the conical flask was $150 \mathrm{~mL}$. At $\mathrm{pH} 5.0$, the highest enzyme activity was obtained, reaching $69.9 \mathrm{U} \mathrm{mL}^{-1}$ crude enzyme.

\section{Separation and purification of alcohol dehydrogenase}

In this research, the separation and purification experiments of alcohol dehydrogenase were also carried out. Alcohol dehydrogenase is an intracellular enzyme, so the cell was collected in the extraction process of the alcohol dehydrogenase. The cell was then broken by ultrasonic method to obtain

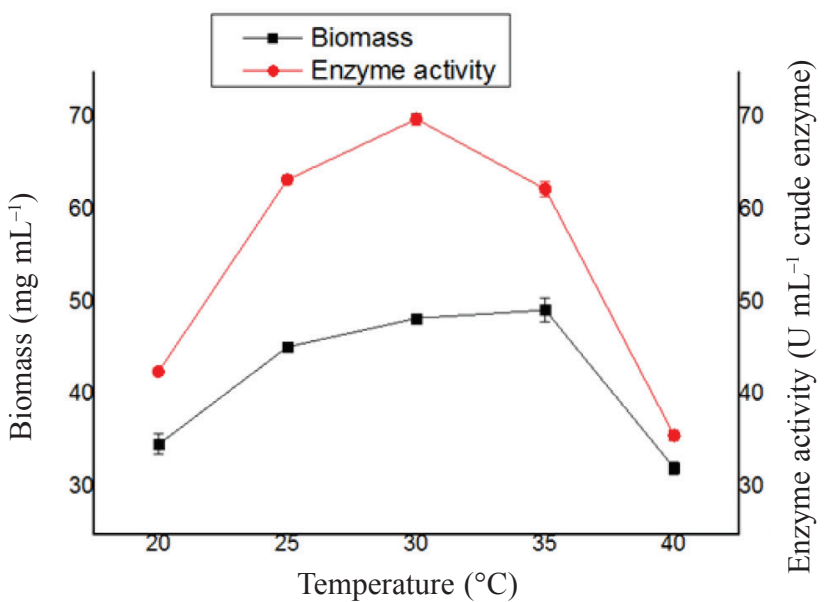

Fig. 2 - Effect of temperature on enzyme fermentation performance

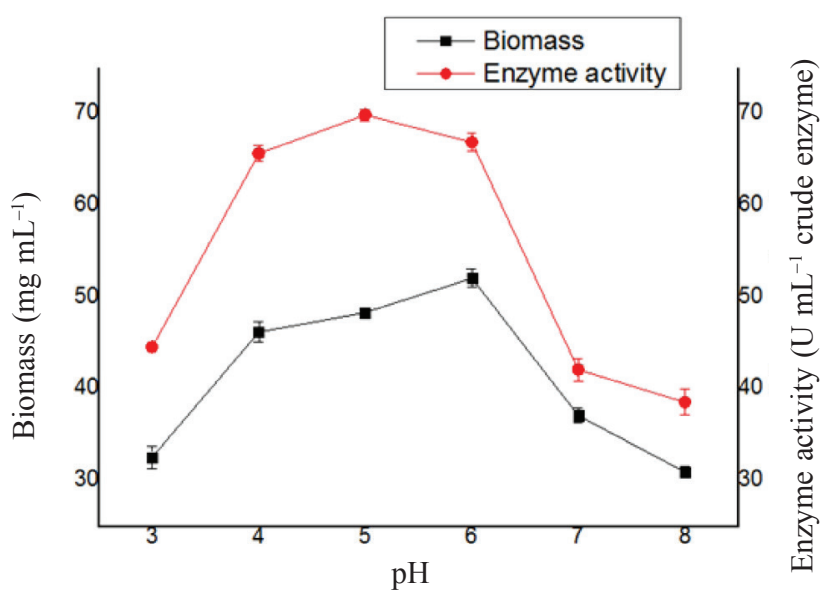

Fig. 3 - Effect of pH on enzyme fermentation performance

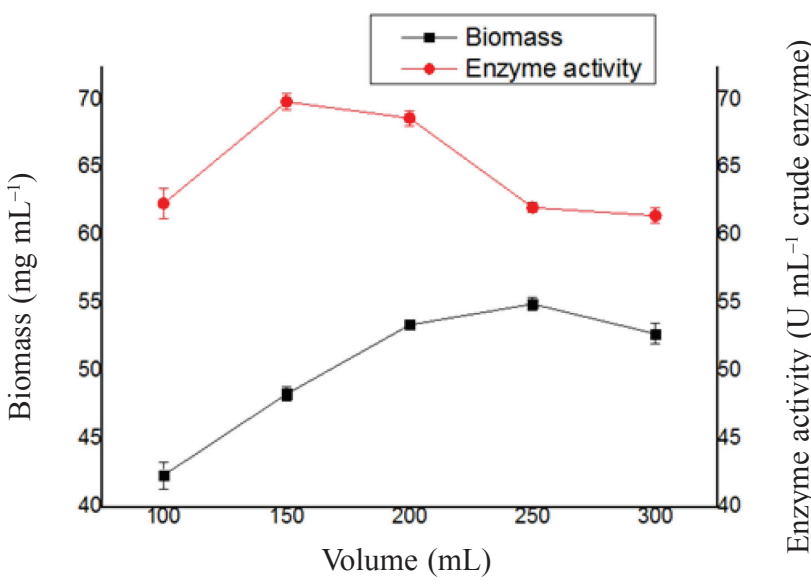

Fig. 4 - Effect of flask volume on enzyme fermentation performance

the crude enzyme solution. In order to determine the effect of ultrasonic time on the enzyme activity, different ultrasonic times were set to deal with the cells. The results obtained are shown in Fig. 5. The results showed that the treatment time was very important for the enzyme extraction process. When the 


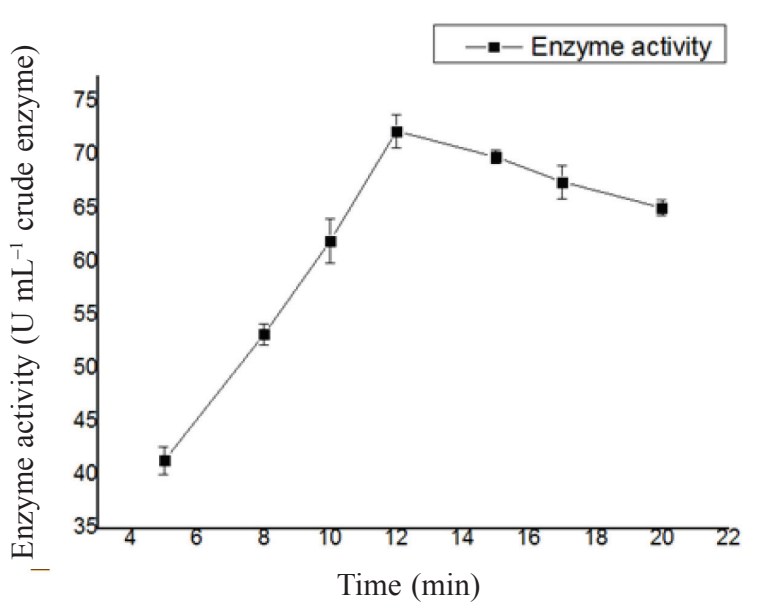

Fig. 5 - Effect of treating time on enzyme separation

treatment time was too short, the yeast cells could not be completely broken. However, when the treatment time was too long, the temperature changed because of the heat, which decreased the activity of the yeast cells. When the full treatment time of the ultrasonic wave was about 12 min under power of $320 \mathrm{~W}$, the enzyme activity of the crude enzyme reached the highest. Therefore, in the following experiments, the total ultrasonic treatment time was 12 min.

Purification of alcohol dehydrogenase is very important in the research of ADH properties. Cabrera et $a l .{ }^{26}$ used metal-affinity chromatography for purification of alcohol dehydrogenase. Madhusudhan et al..$^{27}$ effectively purified alcohol dehydrogenase from yeast using aqueous two-phase extraction. The purification method of the enzyme used in this research was salting out and dialysis method. By adding inorganic salt (sodium chloride, sodium sulfate magnesium sulfate, ammonium sulfate, etc.) to the solution with a certain concentration, some components of lower solubility in water solution were separated from the mixture. The solubility of proteins in aqueous solution was determined by the degree of the hydrophilic group and the protein molecule with the charge. When neutral salt was added to the protein solution, the affinity between salt and water molecules was more than water and protein, and the water film around the protein molecules was weakened or had even disappeared. In addition, when neutral salt was added to the protein solution, the protein surface charge changed, which led to the reduction of protein solubility, so the protein molecules were aggregated and precipitated. The crude enzyme mixture was put in an ice bath and ammonium sulfate was added into the solution to reach certain saturation, from $20 \%$ to $60 \%$, under the action of magnetic stirrer. When saturation reached $35 \%$, the precipitation appeared. When saturation reached $50 \%$, the total enzyme activity was the highest. Salt concentration was related to the salting out effect. If the combination between the salt agent and water was more intense, the salting out effect was stronger. When the salt saturation was too low, the solvation effect was low; therefore, the salting out effect was poor and without precipitation.

\section{Enzyme properties}

Finally, the enzyme properties were studied. The catalytic activity of the enzyme at different $\mathrm{pH}$ values was measured. The dissociation state of enzyme molecules at different $\mathrm{pH}$ values was different. At the same time, at different ionization states, the substrate binding and catalytic activity were also different. At the most suitable $\mathrm{pH}$, the activity of the enzyme reached the highest. In addition, the activity of the enzyme was measured in different buffer solutions. Also at the same time, the enzyme was dissolved in the buffer solution for $1 \mathrm{~h}$ and $2 \mathrm{~h}$ at the temperature of $30{ }^{\circ} \mathrm{C}$. Residual enzyme activity was measured to judge whether the stability of alcohol dehydrogenase had changed under the conditions of different $\mathrm{pH}$ values. The results are presented in Fig. 6. The stability of the enzyme was related to the enzyme molecular structure and the chemical bonding and groups. In certain solutions, the chemical bonds of the molecular structure of enzyme had changed, and the active groups could have been destroyed, thus affecting enzyme activity. In this experiment, the enzyme activity reached highest at $\mathrm{pH}$ 7. The stability of the enzyme was also the best at $\mathrm{pH} \mathrm{7.} \mathrm{The} \mathrm{stability} \mathrm{of} \mathrm{the} \mathrm{enzyme}$ was weaker in strong acid or alkaline conditions.

The catalytic activity of the enzyme at different temperatures was also measured. The catalytic action of the enzyme was affected by temperature. It was the same with the general chemical reaction, and higher temperature could increase the speed of

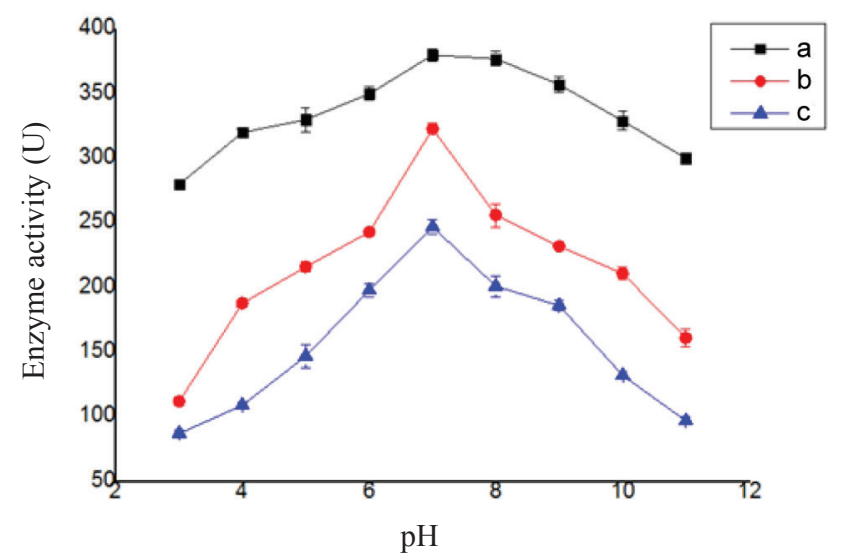

Fig. 6 - Effect of pH on enzyme activity: a) enzyme activity under different $p H$; b) residual enzyme activity after $1 h$; c) residual enzyme activity after $2 \mathrm{~h}$ 


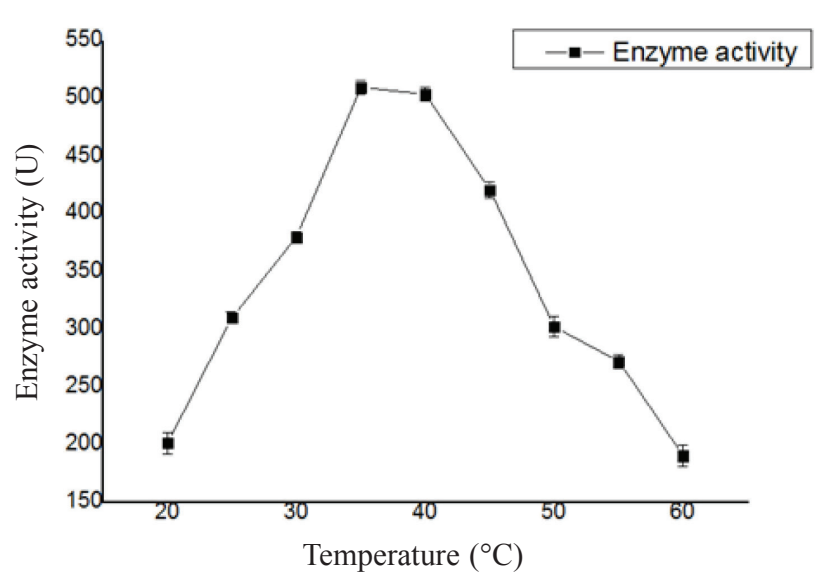

Fig. 7 - Effect of temperature on enzyme activity

the enzymatic reaction. On the other hand, high temperature could cause protein denaturation leading to the inactivation of the enzyme. The activity of the enzyme under different temperatures was measured. The results are presented in Fig. 7. The effect of temperature on enzyme activity was great. The most suitable temperature for the enzyme reaction was $35^{\circ} \mathrm{C}$, and below this temperature the enzyme activity decreased. In addition, above this temperature, the activity decreased below the denaturation temperature.

In summary, the optimal $\mathrm{pH}$ of $\mathrm{ADH}$ activity was 6-9. Maximum activity was reached at $\mathrm{pH} 7$. The optimum temperature of $\mathrm{ADH}$ activity was $35^{\circ} \mathrm{C}$, and when the temperature was higher than $40{ }^{\circ} \mathrm{C}$, the activity of the enzyme decreased sharply.

\section{Conclusion}

The utilization of algae for bioethanol production has many advantages due to their abundance, high photosynthetic efficiency, and production rate. A novel algae fermentation strain was obtained, which was $99 \%$ identical to Meyerozyma guilliermondii. Ethanol fermentation experiments of this strain were performed. This strain is able to produce alginate lyase and alcohol dehydrogenase at the same time. At present, there is no research on the fermentation conditions, separation, and purification of alcohol dehydrogenase of Meyerozyma guilliermondii. In this research, the fermentation conditions of Meyerozyma guilliermondii, the separation and purification process of alcohol dehydrogenase, and the performance study of alcohol dehydrogenase was studied. According to the experiments, the optimum fermentation conditions for enzyme production were as follows: fermentation medium with alginate, initial $\mathrm{pH} 5.0$, and $30^{\circ} \mathrm{C}$. The total capacity of the conical flask was $150 \mathrm{~mL}$. At $\mathrm{pH}$ 5.0, the highest enzyme activity was ob- tained, which reached $69.9 \mathrm{U} \mathrm{mL}^{-1}$ crude enzyme. Alcohol dehydrogenase is an intracellular enzyme so the cell was collected firstly in the extraction process of the alcohol dehydrogenase. The cell was then broken by ultrasonic method to obtain the crude enzyme solution. The optimal ultrasonic procedure was: ultrasonic disruption for $1 \mathrm{~s}$, pause $3 \mathrm{~s}$, and the time of the procedure was $12 \mathrm{~min}$ at the power of $320 \mathrm{~W}$. The purification method of the enzyme used in this research was salting out and dialysis method. When saturation reached $50 \%$, the total enzyme activity was the highest. Finally, the enzyme properties were studied in this research. The catalytic activity of the enzyme at different $\mathrm{pHs}$ and temperatures was measured. The optimal $\mathrm{pH}$ of ADH activity was 6-9. Maximum activity was reached at $\mathrm{pH}$ 7. The optimum temperature of $\mathrm{ADH}$ activity was $35^{\circ} \mathrm{C}$, and when the temperature was higher than $40{ }^{\circ} \mathrm{C}$, the activity of the enzyme decreased sharply.

\section{ACKNOWLEDGMENTS}

This work was supported by Colleges and Universities in Hebei Province science and technology research project (Education Science Research Program of Hebei Provincial Department Z2012068), Independent research program of young teachers in Yanshan University 14LGA018, and National Natural Science Foundation of China 21476190.

\section{References}

1. Choi, I. S., Kim, J. H., Wi, S. G., Kim, K. H., Bae, H. J., Bioethanol production from mandarin (Citrus unshiu) peel waste using popping pretreatment, Appl. Energy. 102 (2013) 204.

doi: https://doi.org/10.1016/j.apenergy.2012.03.066

2. Lee, M., Cho, S., Kim, J., A comprehensive model for design and analysis of bioethanol production and supply strategies from lignocellulosic biomass, Renew. Energ. 112 (2017) 247.

doi: https://doi.org/10.1016/j.renene.2017.05.040

3. Horn, S. J., Aasen, I. M., Østgaard, K., Ethanol production from seaweed extract, J. Ind. Microbiol. Biotechnol. 25 (2000) 249. doi: https://doi.org/10.1038/sj.jim.7000065

4. Zhang, W., Xiong, R., Wei, G., Biological flocculation treatment on distillery wastewater and recirculation of wastewater, J. Hazard. Mater. 172 (2009) 1252. doi: https://doi.org/10.1016/j.jhazmat.2009.07.150

5. Somma, D., Lobkowicz, H., Deason, J. P., Growing America's fuel: an analysis of corn and cellulosic ethanol feasibility in the United States, Clean. Technol. Environ. Policy 12 (2010) 373. doi: https://doi.org/10.1007/s10098-009-0234-3

6. Mesa, L., González, E., Cara, C., Ruiz, E., Castro, E., Mussatto, S. I., An approach to optimization of enzymatic hydrolysis from sugarcane bagasse based on organosolv. pretreatment, J. Chem. Technol. Biotechnol. 85 (2010) 1092. doi: https://doi.org/10.1002/jctb.2404 
7. OECD/FAO, OECD-FAO Agricultural Outlook, OECD Publishing, 2014

8. Zhang, W., Bai, A., Chen, X., Wei, G., Ethanol production from acid hydrolyzates of corn straw with co-immobilized microorganisms, Energy Source: Part A 34 (2012) 1206. doi: https://doi.org/10.1080/15567031003681960

9. Patel, H., Chapla, D., Shah, A., Bioconversion of pretreated sugarcane bagasse using enzymatic and acid followed by enzymatic hydrolysis approaches for bioethanol production, Renew. Energ. 109 (2017) 323.

doi: https://doi.org/10.1016/j.renene.2017.03.057

10. Zhang, W., Wei, G., Effects of lignocellulose acid-hydrolysis by-products on ethanol fermentation of xylose, Energy Source: Part A 34 (2012) 1178. doi: https://doi.org/10.1080/15567030903581502

11. Kim, H. M., Wi, S. G., Jung, S., Song, Y., Bae, H. J., Efficient approach for bioethanol production from red seaweed Gelidium amansii, Bioresour. Technol. 175 (2015) 128 doi: https://doi.org/10.1016/j.biortech.2014.10.050

12. Uju, Wijayanta, A. T., Goto, M., Kamiya, N., Great potency of seaweed waste biomass from the carrageenan industry for bioethanol production by peracetic acideionic liquid pretreatment, Biomass and Bioenergy 81 (2015) 63 doi: https://doi.org/10.1016/j.biombioe.2015.05.023

13. Jung, K. A., Lim, S., Kim, Y., Park, J. M., Potential of macroalgae as feedstock biorefinery, Bioresour. Technol. 135 (2013) 182 doi: https://doi.org/10.1016/j.biortech.2012.10.025

14. Wargacki, A. J., Leonard, E., Maung, W. N., Regitsky, D. D., Santos, C. N. S., Kim, P. B., Cooper, S. R., Raisner, R. M., Herman, A., Sivitz, A. B., Lakshmanaswamy, A., Kashiyama, Y., Baker, D., Yoshikuni, Y., An engineered microbial platform for direct biofuel production from brown macroalgae, Science 335 (2012) 308. doi: https://doi.org/10.1126/science. 1214547

15. Zhang, W., Zhang, J., Cui, H., The isolation and performance studies of an alginate degrading and ethanol producing strain, Chem. Biochem. Eng. Q. 28 (2014) 391. doi: https://doi.org/10.15255/CABEQ.2013.1888

16. Paquin, C. E., Williamson, V. M., Ty insertions account for most of the spontaneous antimycin A resistance mutations during growth at $15^{\circ} \mathrm{C}$ of Saccharomyces cerevisiae strains lacking ADHI, Mol. Cell. Biol. 7 (1986) 70 doi: https://doi.org/10.1128/MCB.6.1.70

17. Ohbuchi, K., Ishikawa, Y., Kanda, A., Hamachi, M., Nunokawa, Y., Alcohol dehydrogenase I of sake yeast Saccha- romyces cerevisiae Kyokai No. 7, J. Ferment. Bioeng. 81 (1996) 125.

doi: https://doi.org/10.1016/0922-338X(96)87589-1

18. Zhong, Z., Li, Q., Tang, X., Qiu, Y., Improvement of the glycerol preserving method, Practical Preventive Medicine 12 (2005) 670.

19. Mao, G., Zhang, X., Zhang, Y., Di, Y., Extraction technology research of alcohol dehydrogenase from abandoned beer yeast, Journal of Shanxi University of Science \& Technology 25 (2007) 41.

20. Wu, G., Jin, F., Wu, Y., Study on fermentation conditions of alcohol dehydrogenase from Saccharomyces cerevisiae, Science and technology of food industry 30 (2009) 176. doi: https://doi.org/10.1016/j.enzmictec.2004.12.015

21. Kayali, H. A., Tarhan, L., Soran, H., Variations of alcohol dehydrogenase activity and fermentative pyruvate, ethanol production of $F$. equiseti and $F$. acuminatum depend on the yeast extract and urea concentrations, Enzyme Micro. Technol. 36 (2005) 706.

22. Plapp, B. V., Lee, A. T., Khanna, A., Pryor, J. M., Bradykinetic alcohol dehydrogenases make yeast fitter for growth in the presence of allyl alcohol, Chemico-Biological Interactions 202 (2013) 104. doi: https://doi.org/10.1016/j.cbi.2012.11.010

23. Harun, R., Danquah, M. K., Forde, G. M., Microalgal biomass as a fermentation feedstock for bioethanol production, J. Chem. Technol. Biotechnol. 85 (2010) 199.

24. Lee, S. M., Lee, J. H., Effect of sludge treatment on biogas production from Saccharina japonica ethanol fermentation by-products, J. Ind. Eng. Chem. 21 (2015) 711. doi: https://doi.org/10.1016/j.jiec.2014.03.041

25. Takeda, H., Yoneyama, F., Kawai, S., Hashimoto, W., Mura$t a, K$., Bio-ethanol production from marine biomass alginate by metabolically engineered bacteria, Energy Environ. Sci. 4 (2011) 2575. doi: https://doi.org/10.1039/c1ee01236c

26. Cabrera, N., Rangel, P., Munoz, R. H., Montfort, R. P., Purification of alcohol dehydrogenase from entamoeba histolyticaand Saccharomyces cerevisiae using zinc-affinity chromatography, Protein Expr. Purif. 10 (1997) 340. doi: https://doi.org/10.1006/prep.1997.0742

27. Madhusudhan, M. C., Raghavarao, K. S. M. S., Nene, S., Integrated process for extraction and purification of alcohol dehydrogenase from Baker's yeast involving precipitation and aqueous two phase extraction, Biochem. Eng. J. 38 (2008) 414. doi: https://doi.org/10.1016/j.bej.2007.08.007 